\author{
ELWIRA MARSZAŁKOWSKA-KRZEŚ \\ ORCID: 0000-0003-3276-4438 \\ Uniwersytet Wrocławski \\ Instytut Prawa Cywilnego \\ Zakład Postępowania Cywilnego
}

\title{
POSTĘPOWANIE O USTALENIE NIEZASADNOŚCI AKTUALIZACJI OPŁATY Z TYTUŁU UŻYTKOWANIA WIECZYSTEGO
}

\begin{abstract}
Abstrakt: W ramach opracowania opisano podstawy do wypowiedzenia wysokości opłaty z tytułu użytkowania wieczystego, wyjaśniono zasady sporządzania operatu szacunkowego nieruchomości. Przedstawiono także znaczenie aktualności operatu szacunkowego nieruchomości, jego charakter prawny oraz omówiono sposób postępowania w wypadku wypowiedzenia wysokości opłaty użytkownikowi wieczystemu.
\end{abstract}

Słowa kluczowe: użytkowanie wieczyste, opłata, operat szacunkowy nieruchomości

\section{UWAGI WSTĘPNE}

Wniosek o ustalenie niezasadności wysokości dokonanej aktualizacji opłaty rocznej z tytułu użytkowania wieczystego nieruchomości gruntowej i zaoferowania opłaty rocznej w nowej wysokości w wypadku wniesienia sprzeciwu od orzeczenia właściwego miejscowo samorządowego kolegium odwoławczego zastępuje pozew, jaki wnoszony jest w sprawach cywilnych. W związku z tym warto już na etapie składania takiego wniosku zadbać, aby spełnione zostały niezbędne wymogi pozwu w rozumieniu przepisów kodeksu postępowania cywilnego ${ }^{1}$, przy jednoczesnym uwzględnieniu specyfiki postępowania związanego z rozpoznawaniem wniosku o niezasadność aktualizacji opłaty z tytułu użytkowania wieczystego, a następnie sprzeciwu od orzeczenia właściwego miejscowo samorządowego kolegium odwoławczego.

1 Ustawa z dnia 17 listopada 1964 roku Kodeks postępowania cywilnego (tekst jedn. Dz.U. z 2019 r. poz. 1460 ze zm.), dalej: k.p.c. 


\section{PODSTAWY DO WYPOWIEDZENIA WYSOKOŚCI OPŁATY Z TYTUŁU UŻYTKOWANIA WIECZYSTEGO}

Aktualizacji opłaty rocznej dokonuje właściwy organ, wypowiadając w formie pisemnej wysokość dotychczasowej opłaty w terminie do dnia 31 grudnia roku poprzedzającego oraz przesyłając równocześnie ofertę przyjęcia nowej wysokości opłaty rocznej. W wypowiedzeniu należy wskazać sposób obliczenia nowej wysokości opłaty rocznej i pouczyć użytkownika wieczystego o sposobie zakwestionowania wypowiedzenia. Do wypowiedzenia dołącza się informację o wartości nieruchomości, o której mowa w art. 77 ust. 3, oraz o miejscu, w którym można zapoznać się z operatem szacunkowym. Do doręczenia wypowiedzenia stosuje się przepisy kodeksu postępowania administracyjnego (art. 78 ust. 1 ustawy o gospodarce nieruchomościami ${ }^{2}$ ). Ciężar dowodu, że istnieją przesłanki aktualizacji opłaty rocznej, spoczywa na właściwym organie (art. 78 ust.3 u.g.n.). Mając na względzie regulację zawartą w przepisie art. 11 ust. 1 u.g.n., nie ulega wątpliwości, że „właściwy organ” to organ osoby prawnej, która jest właścicielem nieruchomości oddanej w użytkowanie wieczyste, uprawniony do podejmowania za nią czynności w zakresie stosunku użytkowania wieczystego. Czynności organu winny być identyfikowane z działaniem samego właściciela nieruchomości, tym bardziej że podmiotami stosunku użytkowania wieczystego są — będący właścicielami nieruchomości gruntowej — Skarb Państwa (bądź jednostka samorządu terytorialnego lub związek jednostek samorządu terytorialnego) oraz osoba fizyczna lub prawna, której oddano nieruchomość w użytkowanie wieczyste (art. 232 § 1 k.c. ${ }^{3}$ ). Oświadczenia odnoszące się do treści użytkowania wieczystego, w tym wysokości opłat rocznych, składa użytkownikowi wieczystemu właściciel nieruchomości, za którą działa organ ${ }^{4}$.

Jak dostrzeżono w judykaturze, narzucenie w przepisie art. 78 ust. 1 ustawy o gospodarce nieruchomościami właścicielowi gruntu przeprowadzającemu aktualizację opłaty rocznej wielu sprecyzowanych obowiązków w zakresie treści wypowiedzenia ma charakter ochronny wobec użytkownika wieczystego. Obowiązki te powinny być zatem traktowane restrykcyjnie. Użytkownik wieczysty powinien otrzymać wraz z wypowiedzeniem dotychczasowej opłaty za użytkowanie wieczyste komplet danych pozwalających mu na ocenę podstawy, zakresu i prawidłowości procedury aktualizacyjnej oraz na ocenę, czy złożone wypowiedzenie jest pełne i przez to wywołuje przewidziany w ustawie skutek, zwłaszcza że właściciel gruntu, którym jest Skarb Państwa lub jednostka samorządu terytorialnego, dysponuje właściwym aparatem urzędniczym. Z pewnością użytkownik wieczy-

2 Ustawa z dnia 21 sierpnia 1997 roku o gospodarce nieruchomościami (tekst jedn. Dz.U. z 2020 r. poz. 65), dalej: u.g.n.

${ }^{3}$ Ustawa z dnia 23 kwietnia 1964 roku Kodeks cywilny (tekst jedn. Dz.U. z 2019 r. poz. 1145), dalej: k.c.

4 Wyrok Sądu Apelacyjnego w Białymstoku z dnia 5 września 2017 roku, I ACa 246/17, LEX nr 2369635. 
sty nie może ponosić konsekwencji błędów lub zaniedbań organu5 ${ }^{5}$. Podstawą do dokonania wypowiedzenia opłaty z tytułu użytkowania wieczystego gruntu jest zwiększenie wartości nieruchomości gruntowej, co powinno zostać wykazane przez właściciela gruntu na podstawie wyceny nieruchomości sporządzonej przez rzeczoznawcę majątkowego (operat szacunkowy nieruchomości). Sam fakt sporządzenia operatu w żadnym wypadku nie jest wystarczający do uznania, że jest on prawidłowy, dlatego powinien być zweryfikowany pod względem merytorycznym także na dalszym etapie przez właściwe miejscowo samorządowe kolegium odwoławcze.

W związku z tym, że podstawą do aktualizacji opłaty z tytułu użytkowania wieczystego gruntu jest zwiększenie wartości nieruchomości gruntowej, ustalenie nowej opłaty z tytułu użytkowania wieczystego bez zwiększenia wartości nieruchomości jest nieuzasadnione. Wraz z upływem czasu na rynku nieruchomości pojawiają się wahania koniunktury i cen. Zmienić się może również sama nieruchomość będąca przedmiotem wyceny — może ona zostać poddana przebudowie, rozbudowie, zmianie funkcji, może ulec niekorzystnemu zdarzeniu losowemu czy zniszczeniu.

Ustawa o gospodarce nieruchomościami w wypadku aktualizacji opłat $\mathrm{z}$ tytułu użytkowania wieczystego wprost odnosi się do świadczeń wniesionych przez użytkownika wieczystego (art. 77 ust. 4 u.g.n.). Budynki i inne urządzenia nieruchomości gruntowej zabudowanej — nieobciążonej prawem użytkowania wieczystego - są trwale związane z gruntem, zarówno w prawnym, jak i fizycznym aspekcie tej więzi, z wyłączeniem przypadków przewidzianych w art. 49 k.c. Te same budynki i inne urządzenia wniesione lub nabyte przez użytkownika wieczystego na gruncie oddanych w użytkowanie wieczyste są nieruchomościami stanowiącymi odrębny od gruntu przedmiot własności (art. $46 \S 1$ k.c.), związany - $\mathrm{w}$ aspekcie prawnym - $\mathrm{z}$ ustanowionym prawem użytkowania wieczystego (art. 235 § 1 i 2 k.c.), a nie z prawem własności nieruchomości gruntowej, przysługującym Skarbowi Państwa lub gminie.

Wymienione różnice stanu prawnego zabudowy nieruchomości gruntowej powodują, że jej wartość rynkowa jako przedmiotu prawa własności przysługującego Skarbowi Państwa lub gminie, określana na potrzeby aktualizacji, powinna uwzględniać atrybuty jej stanu fizycznego tylko w zakresie wynikającym z zakresu prawa własności przysługującego tym podmiotom. Przeciwny pogląd prowadzi do sytuacji, w której zwiększone nakłady użytkownika wieczystego na nieruchomość prowadzą do wzrostu nieuzasadnionych przychodów Skarbu Państwa lub gminy.

5 Postanowienie Sądu Najwyższego - Izba Cywilna z dnia 6 listopada 2018 roku, II CSK 212/18, Legalis nr 1842981 . 


\section{ZASADY SPORZĄDZANIA OPERATU SZACUNKOWEGO NIERUCHOMOŚCI}

Szczegółowe zasady wyceny nieruchomości oraz sporządzania operatu szacunkowego regulują przepisy rozporząazenia Rady Ministrów z dnia 21 września 2004 roku w sprawie wyceny nieruchomości i sporządzania operatu szacunkowego $^{6}$. Wobec tego rzeczoznawca majątkowy nie może dowolnie określać wartości nieruchomości według własnego uznania. Jednocześnie ustawa o gospodarce nieruchomościami określa podstawowe zasady, którymi powinien kierować się rzeczoznawca majątkowy, dokonując wyceny nieruchomości. Zgodnie z przepisem art. 175 ust. 1 u.g.n. rzeczoznawca majątkowy dokonuje wyceny nieruchomości na podstawie zasad wynikających z przepisów prawa i standardów zawodowych, ze szczególną starannością, właściwą zawodowemu charakterowi tych czynności oraz z poszanowaniem reguł etyki zawodowej, kierując się przy tym zasadą bezstronności.

W orzecznictwie wyrażono pogląd, który należy podzielić, że

1. Operat szacunkowy sporządzany przez rzeczoznawcę majątkowego jest jedynym dopuszczalnym przez prawo dowodem określającym wartość nieruchomości w postępowaniu zmierzającym do ustalenia opłaty adiacenckiej. Zgodność opinii rzeczoznawcy majątkowego z przepisami prawa jest o tyle istotna, że wpływa ona bezpośrednio na treść decyzji kształtującej prawa i obowiązki stron postępowania. Jak każdy dowód w sprawie, podlega on ocenie organu administracyjnego, zgodnie z przepisami k.p.a. Organ prowadzący postępowanie nie może wkraczać w merytoryczną zasadność opinii rzeczoznawcy majątkowego, ponieważ nie dysponuje wiadomościami specjalnymi, które posiada biegły. Powinien jednak mimo wszystko dokonać oceny operatu szacunkowego pod względem formalnym, tj. zbadać, czy został on wykonany i podpisany przez uprawnioną osobę, czy zawiera wymagane przepisami elementy, czy nie zawiera niejasności, pomyłek, braków, które powinny być uzupełnione, aby dokument ten miał wartość dowodową. W tym zakresie organ ma więc prawo i obowiązek zbadać, czy przedłożona mu opinia jest zupełna, logiczna i wiarygodna. Dowód z operatu szacunkowego podlega ocenie organu administracji publicznej tak jak każda inna opinia, lecz merytorycznie wiąże organ w tym sensie, że organ nie może samodzielnie zmienić obliczeń rzeczoznawcy. Oceny prawidłowości sporządzenia operatu szacunkowego dokonuje organizacja zawodowa rzeczoznawców majątkowych. W razie stwierdzenia przez organ z własnej inicjatywy lub pod wpływem twierdzeń strony i naprowadzonych przez nią dowodów (np. w postaci kontr ekspertyzy własnej bądź negatywnej oceny organizacji zawodowej rzeczoznawców majątkowych), że istnieją wątpliwości co do prawidłowości operatu — powinien wezwać rzeczoznawcę, w zależności od potrzeb i okoliczności, do złożenia wyjaśnień lub do uzupełnienia dotychczasowej opinii, albo zlecić wykonanie operatu innemu rzeczoznawcy. Jeśli jednak w ocenie organu operat został sporządzony zgodnie z przepisami, wtedy organ nie ma podstaw do dokonania ustaleń odmiennych, niż wynikające $\mathrm{z}$ tego dowodu, co do wartości nieruchomości przed podziałem i po podziale?

${ }^{6}$ Rozporządzenie Rady Ministrów z dnia 21 września 2004 roku w sprawie wyceny nieruchomości i sporządzania operatu szacunkowego (Dz.U. z 2004 r. Nr 207, poz. 2109 ze zm.).

7 Wyrok Wojewódzkiego Sądu Administracyjnego w Krakowie z dnia 13 listopada 2015 roku, II SA/Kr 1252/15, LEX nr 1939268. 
Z tych względów właściciel gruntu oddawanego w użytkowanie wieczyste także samodzielnie przed dokonaniem aktualizacji opłaty z tytułu użytkowania wieczystego, powinien ustalić, czy operat szacunkowy zawiera:

1) opis stanu prawnego nieruchomości na podstawie księgi wieczystej z uwzględnieniem służebności i wzmianek, ewidencji gruntów i budynków — brak takich informacji w operacie szacunkowym sporządzonym przez rzeczoznawcę majątkowego może stanowić zarzut, który powinien zostać rozpatrzony przez sąd;

2) opis dostępu wycenianej nieruchomości do drogi publicznej (bezpośredni dostęp, udział w drodze wewnętrznej, służebność itp.) — nie może to być jednak opis ogólnikowy;

3) opis stanu technicznego i użytkowego nieruchomości;

4) opis aspektów środowiskowych mających wpływ na wartość nieruchomości, w tym rodzaj i stopień zanieczyszczenia środowiska, występujących na obszarze nieruchomości oraz w jej bliskim sąsiedztwie (występowanie na przykład benzyny, oleju, rozpuszczalników, farb, kwasów, chloru, nawozów, pestycydów, azbestu, śmieci, emitentów: gazu, hałasu czy uciążliwych zapachów, jak również transformatorów);

5) analizę lokalnego rynku nieruchomości ze względu na wyceniany typ nieruchomości, obejmującą:

— częstotliwość transakcji tego typu nieruchomościami,

— aktualną liczbę ofert sprzedaży podobnych nieruchomości,

- średnie ceny transakcyjne/stawki czynszu uzyskiwane przy sprzedaży albo wynajęciu nieruchomości danego typu;

6) przedstawienie obliczeń wartości nieruchomości w sposób pozwalający na sprawdzenie całego procesu wyceny wraz z uzasadnieniem przyjętych założeń i poziomu parametrów.

Wprawdzie przepisy nie wprowadzają obligatoryjnego udziału strony (użytkownika wieczystego) przy dokonywaniu oględzin przez biegłego, ale taki udział pozwala przynajmniej na weryfikację: czy biegły w ogóle dokonał oględzin, czy też wycena została dokonana tylko na podstawie wcześniejszych wycen innych nieruchomości podobnych. Zaniechanie powiadomienia przez rzeczoznawcę majątkowego o zamiarze dokonania oględzin uniemożliwia użytkownikowi wieczystemu przedstawienie sporządzającemu wycenę, czy i jakiego rodzaju nakłady zostały poczynione przez użytkownika wieczystego. Ułatwi to także rzeczoznawcy majątkowemu dokonanie prawidłowej wyceny wartości nieruchomości.

Należy zgodzić się ze stanowiskiem, wyrażonym przez Wojewódzki Sąd Administracyjny w Gdańsku w wyroku z dnia 12 maja 2010 roku, że:

1. Skoro na organie administracji spoczywa obowiązek oceny treści operatu szacunkowego, operat ten powinien być sporządzony w sposób umożliwiający dokonanie, przy zastosowanym przez rzeczoznawcę podejściu do wyceny, analizy logiczności i poprawności wniosków operatu. 2. Wnioski operatu winny być możliwe do sprawdzenia na podstawie treści operatu, a wszelkie zastosowane korekty i współczynniki szczegółowo wyjaśnione. 3. Brak dostatecznego wyjaśnienia 
sposobu dokonania wyceny uniemożliwia dokonanie oceny przydatności dowodowej operatu szacunkowego, a biegły powinien mieć na względzie, iż sporządza operat dla osób, które nie zajmują się zawodowo wyceną nieruchomości, niezbędne jest więc dokładne wyjaśnienie sposobu, w jaki biegły doszedł do zawartych w operacie wniosków, gdyż umożliwia to ocenę prawidłowości tego dowodu. 4. Rzeczoznawca, sporządzając operat szacunkowy, winien opierać się na danych, które możliwe są do zweryfikowania. Biegły, korzystając z umów w celu ustalenia ceny, w razie wątpliwości strony co do wiarygodności dokonanych ustaleń, może wskazać źródła przyjętych do dokonania obliczeń ustaleń — w tym numery i daty zawartych aktów notarialnych ${ }^{8}$.

Standardy zawodowe wyznaczają zasady, jakimi powinni kierować się rzeczoznawcy majątkowi, wykonując czynności zawodowe. Są one uzupełnieniem reguł przewidzianych we wspomnianej wcześniej ustawie i rozporządzeniu. Ich celem jest doprecyzowanie szczegółowych kwestii pojawiających się w trakcie dokonywanych wycen. Standardy zawodowe są zatem podstawą oceny świadczonych przez rzeczoznawców majątkowych usług oraz podstawą prawną ich kwestionowania. Ustawa z dnia 20 lipca 2017 roku o zmianie ustawy o gospodarce nieruchomościami oraz niektórych innych ustaw ${ }^{9}$ dokonała od 1 września 2017 roku zmiany w przepisie art. 175 ust. 6 u.g.n. przez wprowadzenie po stronie ministra właściwego do spraw budownictwa, planowania i zagospodarowania przestrzennego oraz mieszkalnictwa (obecnie minister inwestycji i rozwoju) obowiązku ustalenia oraz ogłoszenia w drodze obwieszczenia obowiązujących standardów zawodowych ${ }^{10}$.

Zgodnie z § 28 ust. 4 powołanego rozporządzenia przy określaniu wartości nieruchomości gruntowej zabudowanej w celu aktualizacji opłat $\mathrm{z}$ tytułu użytkowania wieczystego stosuje się przepisy ust. 1 i 2 . Zgodnie z nimi na potrzeby ustalenia ceny nieruchomości gruntowej niezabudowanej oddawanej w użytkowanie wieczyste oraz aktualizacji opłat z tego tytułu określa się jej wartość jako przedmiotu prawa własności, stosując podejście porównawcze. Przy określaniu wartości, o której mowa w ust. 1 , stosuje się, z zastrzeżeniem $\S 27$, ceny transakcyjne sprzedaży nieruchomości niezabudowanych jako przedmiotu prawa własności. Jeżeli nieruchomość gruntowa oddawana w użytkowanie wieczyste jest zabudowana, po określeniu jej wartości jako przedmiotu prawa własności z wartości tej wyodrębnia się wartość gruntu, budynków lub ich części oraz innych urządzeń. Ustawodawca zaleca przy tym, aby określenie wartości przede wszystkim oprzeć na transakcjach rynkowych sprzedaży nieruchomości jako przedmiotu prawa własności, dopiero w wypadku braku takich transakcji na rynku można by wykorzystać transakcje przedmiotu prawa użytkowania wieczystego.

Słowo „przysługuje” odnosi się wprost do stanu prawnego nieruchomości wycenianej, a dokładniej do określenia w nieruchomości zakresu obszaru wła-

8 Wyrok Wojewódzkiego Sądu Administracyjnego w Gdańsku z dnia 12 maja 2010 roku, II SA/Gd 44/10, LEX nr 674080.

9 Dz.U. z 2017 r. poz. 1509.

10 Obwieszczenie Ministra Infrastruktury i Budownictwa z dnia 1 września 2017 roku w sprawie standardu zawodowego rzeczoznawców majątkowych $\mathrm{nr}$ 1. Wycena dla zabezpieczenia wierzytelności (Dz.Urz.MIiB z 2017 r. poz. 59). 
sności Skarbu Państwa lub gminy. Należy pamiętać, że prawo użytkowania wieczystego w konsekwencji prowadzi do odrębnej od gruntu własności budynków budowli i urządzeń. Ich właścicielem jest użytkownik wieczysty, tym samym nie przysługują one Skarbowi Państwa lub gminie. Oczywiste jest, że ma to bardzo istotne znaczenie dla wartości nieruchomości określanej na potrzeby aktualizacji opłaty z tytułu użytkowania wieczystego, zwłaszcza jeśli chodzi o kwestię uzbrojenia terenu. W tym miejscu warto wskazać, że poprzez uzbrojenie terenu należy rozumieć stworzenie warunków do bezpośredniego podłączenia nieruchomości do poszczególnych urządzeń infrastruktury technicznej, a nie istnienie na danej nieruchomości sieci czy też przyłączy.

Nawet w wypadku ewentualnego wzrostu wartości nieruchomości przy określaniu jej wartości w celu aktualizacji opłaty należy wziąć pod uwagę przywołany przepis, w myśl którego określa się jej wartość jako przedmiotu prawa własności, które przysługuje Skarbowi Państwa lub gminie. W świetle powyższego postanowienia Skarbowi Państwa lub gminie w tym wypadku nie przysługuje prawo własności do elementów uzbrojenia terenu. Niewątpliwie cechy takie jak uzbrojenie oraz dojazd do nieruchomości mają bardzo istotne znaczenie dla wartości nieruchomości określanej na potrzeby aktualizacji opłaty z tytułu użytkowania wieczystego, dlatego rzeczoznawca nie może pomijać w swych ustaleniach kwestii, czy obecne uzbrojenie i dojazd do nieruchomości wiązały się z poniesieniem nakładów na nieruchomość przez właściciela, czy użytkownika wieczystego. Dokonując wykładni § 28 ust. 1 rozporządzenia stanowiącego, że do celów aktualizacji opłat z tytułu użytkowania wieczystego określa się wartość nieruchomości gruntowej jako przedmiotu prawa własności, które przysługuje Skarbowi Państwa lub gminie, należy uznać, że wątpliwe jest, aby w zamyśle ustawodawcy wprowadzenie pojęcia „przysługuje” do aktu normatywnego rangi rozporządzenia miało na celu podkreślenie faktu, że właścicielem gruntu oddanego w użytkowanie wieczyste jest Skarb Państwa lub gmina. W świetle dyspozycji $§ 28$ w zw. z $§ 5$ ust. 1 rozporządzenia wartość rynkową, o której mowa w art. 77 ust. 1, należy określić podejściem porównawczym na podstawie analizy cen transakcyjnych podobnych nieruchomości. Nieuwzględnienie dyspozycji art. $235 \S 1$ i 2 k.c. powodowałby, że przy określaniu wartości rynkowej nieruchomości gruntowej jako przedmiotu prawa własności przysługującego Skarbowi Państwa lub gminie konieczne stałoby się pozyskanie informacji o cenach transakcyjnych uzyskanych przy sprzedaży gruntów — jako przedmiotu prawa własności — których zabudowa nie jest przedmiotem transakcji. Wartość rynkowa oszacowana bez uwzględnienia regulacji art. 235 k.c. prowadzi wprost do zawyżenia wartości oszacowania. Zawyżenie to dotyczy takiego zakresu, w jakim stan nieruchomości przyjęty według art. 134 wykracza poza właściwy stan prawny.

Istotną kwestią jest tutaj także okoliczność, że w wielu wypadkach infrastruktura techniczna w postaci sieci ciepłowniczych, energetycznych, wodociągowych, kanalizacyjnych oraz telekomunikacyjnych została wniesiona do spółek prawa 
handlowego i nie stanowi własności gminy, nie może więc być brana pod uwagę przy ustalaniu wartości nieruchomości na potrzeby aktualizacji opłat z tytułu użytkowania wieczystego. Jeżeli sieci są własnością spółek prawa handlowego, to nie ma najmniejszego znaczenia, kto jest właścicielem udziałów lub akcji tych spółek. Nie są bowiem one wtedy własnością gminy lub Skarbu Państwa i nie mogą być podstawą do uwzględnienia w wycenie w postaci atrybutów cenotwórczych.

Mając to na uwadze, należy stwierdzić, że w procesie określania wartości nieruchomości istnieje konieczność rozpoznania stanu prawnego nieruchomości sąsiadujących $\mathrm{z}$ wycenianymi, nie tylko według stanu obecnego, lecz także według stanów historycznych.

Zgodnie z art. 153 ust. 1 u.g.n., określającym zasady i warunki użycia w wycenie nieruchomości podejścia porównawczego (podobnie rzecz ujmuje $\S 4$ ust. 1 i 2 rozporządzenia Rady Ministrów w sprawie wyceny nieruchomości i sporządzania operatu szacunkowego), podejście to polega na określeniu wartości nieruchomości przy założeniu, że wartość ta odpowiada cenom, jakie uzyskano za nieruchomości podobne, które były przedmiotem obrotu rynkowego. Ceny te koryguje się ze względu na cechy różniące nieruchomości podobne do nieruchomości wycenianej oraz uwzględnia się zmiany poziomu cen wskutek upływu czasu. Podejście porównawcze stosuje się, gdy są znane ceny i cechy nieruchomości podobnych do wycenianej nieruchomości. Zasadnie podkreśla się w orzecznictwie, że pod pojęciem „nieruchomości podobne, porównywalne”

należy rozumieć takie, których stan prawny, fizyczny i funkcjonalny jest najbardziej do siebie zbliżony. W przypadku wystąpienia odmienności wycena określająca wartość podlega stosownej korekcie opartej na wychwyceniu istotnych różnic, tj. takich, które mogą wpływać na wartość. Przy metodzie korygowania ceny średniej do porównań przyjmuje się z rynku właściwego ze względu na położenie wycenianej nieruchomości co najmniej kilkanaście nieruchomości podobnych, które były przedmiotem obrotu rynkowego i dla których znane są ceny transakcyjne, warunki zawarcia transakcji oraz cechy tych nieruchomości ${ }^{11}$.

\section{AKTUALNOŚĆ OPERATU SZACUNKOWEGO NIERUCHOMOŚCI}

W związku z tym, że wycenę nieruchomości sporządza się na konkretny dzień, może zdarzyć się sytuacja, że po upływie jakiegoś okresu wyżej opisane zmiany wpłyną na wartość nieruchomości. Z tego względu ustawodawca w przepisie art. 156 ust. 3 u.g.n. ograniczył ważność operatu szacunkowego do maksymalnie 12 miesięcy. Zgodnie z przedmiotowym przepisem operat szacunkowy może być wykorzystywany do celu, dla którego został sporządzony, przez okres 12 miesięcy od daty jego sporządzenia, chyba że wystąpiły zmiany uwarunkowań prawnych lub istotne zmiany czynników, o których mowa w przepisie

11 Wyrok Wojewódzkiego Sądu Administracyjnego w Warszawie z dnia 9 lutego 2012 roku, I SA/Wa 1625/11, Legalis nr 474144. 
art. 154 u.g.n. Wprawdzie stosownie do art. 156 ust. 4 u.g.n. operat szacunkowy może być wykorzystywany po upływie okresu, o którym mowa w ust. 3 , ale wyłącznie po potwierdzeniu jego aktualności przez rzeczoznawcę majątkowego. Potwierdzenie aktualności operatu szacunkowego następuje przez umieszczenie stosownej klauzuli w operacie szacunkowym przez rzeczoznawcę, który go sporządził, oraz dołączenie do operatu szacunkowego analizy potwierdzającej, że od daty jego sporządzenia nie wystąpiły zmiany uwarunkowań prawnych lub istotne zmiany czynników, o których mowa w art. 154 u.g.n. Po potwierdzeniu aktualności operat szacunkowy może być wykorzystywany do celu, dla którego został sporządzony, w kolejnych 12 miesiącach, licząc od dnia upływu okresu, o którym mowa w ust. 3, chyba że wystąpią zmiany uwarunkowań prawnych lub istotne zmiany czynników, o których mowa w art. 154. W orzecznictwie jednolicie przyjmuje się, że dwunastomiesięczny termin, o którym mowa w art. 156 ust. 3 u.g.n., dotyczy postępowań przed organami obu instancji. W związku z tym na moment wydania przez samorządowe kolegium odwoławcze orzeczenia operat szacunkowy musi być aktualny. Sporządzenie „aktualizacji operatu szacunkowego” nie jest tym samym co „potwierdzenie aktualności operatu szacunkowego"12. Warto zwrócić uwagę, że

Przepis art. 156 ust. 3 u.g.n. odnosi się także do organu odwoławczego jako zobligowanego do ponownego rozpoznania i rozstrzygnięcia sprawy. Wykorzystanie do celów dowodowych operatu szacunkowego po upływie 12 miesięcy, bez potwierdzenia jego aktualności, stanowi naruszenie prawa materialnego, które ma wpływ na wynik sprawy ${ }^{13}$.

\section{CHARAKTER PRAWNY OPERATU SZACUNKOWEGO}

Operat szacunkowy stanowi dokument sporządzany w sposób sformalizowany, uregulowany przepisami $\mathrm{w}$ randze rozporządzenia. To, że przygotowuje go uprawniony rzeczoznawca majątkowy, nie zmienia jego charakteru jako dowodu z opinii biegłego. Jak podkreślił Naczelny Sąd Administracyjny w wyroku z dnia 12 grudnia 1983 roku, przy ocenie opinii biegłego organ administracji publicznej nie może ograniczyć się do powołania na konkluzję zawartą w opinii biegłego, lecz obowiązany jest sprawdzić, na jakich przesłankach biegły oparł konkluzję, i skontrolować prawidłowość jego rozumowania ${ }^{14}$. Kontrola ta polega na sprawdzeniu — biorąc pod uwagę logikę i zasady doświadczenia życiowego

12 Wyrok Wojewódzkiego Sądu Administracyjnego w Warszawie z dnia 18 lutego 2008 roku, I SA/Wa 1630/08, LEX nr 527210.

13 Por. pogląd wyrażony w wyroku Wojewódzkiego Sądu Administracyjnego w Gliwicach z dnia 27 sierpnia 2019 roku, II SA/Gl 344/19, LEX nr 2719869.

14 Wyrok Naczelnego Sądu Administracyjnego z dnia 12 grudnia 1983 roku, II SA 1302/83, ONSA 1983, nr 2, s. 106. 
— prawidłowości rozumowania przeprowadzonego w uzasadnieniu opinii. Z kolei w wyroku Naczelnego Sądu Administracyjnego z dnia 26 stycznia 2006 roku stwierdzone zostało, że organy administracyjne oraz sądy rozpatrujące sprawę mają obowiązek ocenić — na podstawie art. 80 k.p.a. — dowodową wartość złożonego operatu szacunkowego ${ }^{15}$. Podobnie w wyroku z dnia 4 października 2006 roku Naczelny Sąd Administracyjny stwierdził, że o wysokości opłaty decyduje organ administracji, oceniając $\mathrm{w}$ procesie decyzyjnym między innymi wartość dowodową operatu i jego wiarygodność ${ }^{16}$. Na organie zatem spoczywa obowiązek dokładnego wyjaśnienia sprawy oraz podjęcia wszelkich niezbędnych działań zmierzających do prawidłowego określenia wartości.

\section{TRYB POSTĘPOWANIA W PRZYPADKU WYPOWIEDZENIA WYSOKOŚCI OPŁATY UŻYTKOWNIKOWI WIECZYSTEMU GRUNTU}

Zgodnie z przepisem art. 78 ust. 2 u.g.n. użytkownik wieczysty może, w terminie 30 dni od dnia otrzymania wypowiedzenia, złożyć do samorząadowego kolegium odwoławczego właściwego ze względu na miejsce położenia nieruchomości (dalej: kolegium) wniosek o ustalenie, że aktualizacja opłaty rocznej jest nieuzasadniona albo jest uzasadniona w innej wysokości. Wniosek składa się za pośrednictwem właściwego organu. Użytkownik wieczysty po otrzymaniu od właściciela gruntu (Skarbu Państwa lub gminy) wypowiedzenia wysokości dotychczas uiszczanej opłaty z tytułu użytkowania wieczystego może — jeśli nie zgadza się z zasadnością wypowiedzenia - wystąpić do właściwego miejscowo samorządowego kolegium odwoławczego z wnioskiem o uznanie, że wypowiedzenie dotychczasowej opłaty z tytułu użytkowania wieczystego gruntu było niezasadne lub inne niż oferowana kwota opłaty.

Pod wypowiedzeniem wysokości dotychczasowej opłaty z tytułu użytkowania wieczystego i zaoferowaniem innej kwoty powinna podpisać się osoba uprawniona do działania w imieniu Skarbu Państwa lub gminy. Niedopuszczalne jest zaniechanie przedłożenia do dokonanego wypowiedzenia dotychczas obowiązującej opłaty rocznej z tytułu użytkowania wieczystego pełnomocnictwa, pozwalającego na zweryfikowanie osoby podpisanej pod takim wypowiedzeniem w zakresie tego, czy jest umocowana do działania w imieniu właściciela gruntu.

Działanie w imieniu podmiotów uprawnionych (pełnomocnictwo) jest niezbędne do przyjęcia skuteczności dokonania wypowiedzenia. Należy podkreślić,

15 Wyrok Naczelnego Sądu Administracyjnego z dnia 26 stycznia 2006 roku, II OSK 459/05, LEX nr 206473.

16 Wyrok Naczelnego Sądu Administracyjnego z dnia 4 października 2006 roku, I OSK 417/06, LEX nr 281387. 
że wypowiedzenie jest kierowane do użytkownika wieczystego, a umowa użytkowania wieczystego podlega reżimowi przepisów kodeksu cywilnego. W związku z tym w wypadku każdego rodzaju umowy cywilnoprawnej wymaga przedłożenia drugiej stronie stosunku prawnego stosownego umocowania (pełnomocnictwa) do działania. W judykaturze podkreśla się, że:

Czynności organu winny być identyfikowane z działaniem samego właściciela nieruchomości, tym bardziej że podmiotami stosunku użytkowania wieczystego są - będący właścicielem nieruchomości gruntowej — Skarb Państwa (bądź jednostka samorządu terytorialnego lub związek jednostek samorządu terytorialnego) oraz osoba fizyczna lub prawna, której oddano nieruchomość w użytkowanie wieczyste (art. 232 § 1 k.c.).

Usunięcie nieprawidłowości w zakresie potwierdzenia umocowania do występowania w imieniu właściwego organu w żadnym wypadku nie może nastąpić na podstawie wskazania, że takie upoważnienie istniało, lecz należy je przedłożyć przy dokonywaniu czynności oraz potwierdzić czynności dokonane przez nieupoważniony podmiot.

Samorządowe kolegium odwoławcze może w celu rozpoznania wniosku wyznaczyć rozprawę. Od wydanego orzeczenia przysługuje prawo wniesienia sprzeciwu w terminie 14 dni od dnia doręczenia orzeczenia stronom umowy użytkowania wieczystego (art. 80 ust. 1 u.g.n.). Sprzeciw kierowany jest do sądu właściwego miejscowo za pośrednictwem samorządowego kolegium odwoławczego. Strona nie jest zobligowana, aby w sprzeciwie (który nie jest pozwem, gdyż funkcję pozwu pełni wcześniejszy wniosek, złożony na podstawie art. 78 ust. 2 u.g.n.) wskazywać sąd, do którego sprawa miałaby być przekazana, gdyż obowiązek ustalenia właściwego sądu oraz przekazania mu aktu spoczywa na organie, a sprzeciw nie musi być skierowany do sądu ${ }^{17}$. W razie wniesienia sprzeciwu w terminie orzeczenie traci moc, nawet gdy sprzeciw odnosi się tylko do części orzeczenia (art. 80 ust. 3 u.g.n.). Przy czym

procedura rozstrzygania sporów o ustalenie opłaty za użytkowanie wieczyste jest procedurą dwustopniową o charakterze mieszanym, administracyjnym w pierwszym etapie i sądowym w drugim stadium tego postępowania. Ustawa o gospodarce nieruchomościami nie rozstrzyga o tym, jakie czynności winno podjąć SKO w sytuacji, gdy strona spóźnia się z wniesieniem sprzeciwu. Badanie tej przesłanki leży w gestii sądu powszechnego, który na każdym etapie postępowania obowiązany jest badać, czy w sprawie dopuszczalna jest droga sądowa na podstawie art. 202 zdanie drugie k.p.c. Stwierdzając, iż sprzeciw od orzeczenia SKO jest spóźniony, sąd powszechny może jedynie skonkludować, iż nie doszło do otwarcia drogi sądowej. W takiej jednak sytuacji brak jest podstaw do odrzucenia sprzeciwu, ponieważ wbrew literalnej nazwie nie stanowi on środka odwoławczego ani nie inicjuje postępowania. W związku z powyższym stwierdzenie, iż sprzeciw został wniesiony z uchybieniem terminu, może skutkować jedynie odrzuceniem pozwu na podstawie art. $199 \S 1$ pkt 1 k.p.c. ${ }^{18}$

17 A. Prusaczyk, [w:] J. Jaworski et al., Ustawa o gospodarce nieruchomościami. Komentarz, Warszawa 2011, s. 448.

18 Postanowienie Sądu Apelacyjnego w Szczecinie z dnia 28 października 2010 roku, i ACz 375/10, Biul.SASz 2011, nr 2, s. 75-80. 
Tym samym nie dojdzie także do wydania merytorycznego rozstrzygnięcia w sprawie.

\title{
PROCEEDINGS TO DETERMINE THE GROUNDS FOR UPDATING THE PERPETUAL USUFRUCT FEE
}

\author{
Summary
}

As part of the study, the grounds for terminating the perpetual usufruct fee were described, the rules for preparing the appraisal report of the property were explained. The relevance of the current appraisal of the property, its legal nature and the procedure in the event of termination of the fee perpetual usufructuary were also presented.

Keywords: perpetual usufruct, payment, real estate appraisal report

\section{BIBLIOGRAFIA}

Prusaczyk A., [w:] J. Jaworski, A. Prusaczyk, A. Tułodziecki, M. Wolanin, Ustawa o gospodarce nieruchomościami. Komentarz, Warszawa 2011.

\section{ORZECZNICTWO}

Postanowienie Sądu Apelacyjnego w Szczecinie z dnia 28 października 2010 roku, I ACz 375/10, Biul.SASz 2011, nr 2.

Postanowienie Sądu Najwyższego — Izba Cywilna z dnia 6 listopada 2018 roku, II CSK 212/18, Legalis nr 1842981.

Wyrok Naczelnego Sądu Administracyjnego z dnia 12 grudnia 1983 roku, II SA 1302/83, ONSA $1983, \mathrm{nr} 2$.

Wyrok Naczelnego Sądu Administracyjnego z dnia 26 stycznia 2006 roku, II OSK 459/05, LEX nr 206473.

Wyrok Naczelnego Sądu Administracyjnego z dnia 4 października 2006 roku, I OSK 417/06, LEX nr 281387.

Wyrok Sądu Apelacyjnego w Białymstoku z dnia 5 września 2017 roku, I ACa 246/17, LEX nr 2369635.

Wyrok Sądu Apelacyjnego w Białymstoku — i Wydział Cywilny z dnia 6 września 2017 roku, I ACa 246117, Legalis nr 1674192.

Wyrok Wojewódzkiego Sądu Administracyjnego w Gdańsku z dnia 12 maja 2010 roku, II SA/Gd 44/10, LEX nr 674080.

Wyrok Wojewódzkiego Sądu Administracyjnego w Gliwicach z dnia 27 sierpnia 2019 roku, II SA/ Gl 344/19, LEX nr 2719869.

Wyrok Wojewódzkiego Sądu Administracyjnego w Krakowie z dnia 13 listopada 2015 roku, II SA/ Kr 1252/15, LEX nr 1939268.

Wyrok Wojewódzkiego Sądu Administracyjnego w Warszawie z dnia 18 lutego 2008 roku, I SA/Wa 1630/08, LEX nr 527210.

Wyrok Wojewódzkiego Sądu Administracyjnego w Warszawie z dnia 9 lutego 2012 roku, I SA/Wa 1625/11, Legalis $\mathrm{nr} 474144$. 